\title{
COEXISTENCE AND MIXING OF MAGMAS IN THE LATE PRECAMBRIAN ITAPORANGA BATHOLITH, STATE OF PARAÍBA, NORTHEASTERN BRAZIL
}

\author{
GORKI MARIANO* and ALCIDES NÓBREGA SIAL*
}

\begin{abstract}
RESUMO COEXISTÊNCIA E MISTURA DE MAGMAS NO BATÓLITO PRÉ-CAMBRIANO DE ITAPORANGA, ESTADO DA PARAÍBA, NORDESTE DO BRASIL. O cinturão de dobramentos Cachoeirinha-Salgueiro (CCS), de idade pré-cambriana, localiza-se na porção oeste dos estados de Pernambuco e Paraíba e é cortado por inúmeras intrusões de rochas granfticas porfirfticas, cálcio-alcalinas potássicas, na sua porção norte. Esses batólitos foram posicionados sintectonicamente ao Ciclo Brasiliano (=Pan-Africano) e são freqüentemente associados a dioritos potássicos, sugerindo coexistência e mistura entre magmas féísico e máfico. No batólito de Itaporanga, foram mapeados três domínios petrográficos. A zona híbrida caracterizada por intensa mistura entre magmas granítíco e granodiorítíco e diorítíco potássico na borda do batólito. A zona de "commingling", na porção central do batólito, onde rochas graníticas a granodioríticas e diorfticas potássicas são individualizadas em escala de afloramento; e finalmente, porções compostas por rochas félsicas porfiriticas, mais comuns na zona híbrida. A intensa mistura mecânica observada na zona híbrida desenvolveu estruturas migmatíticas (estromática e menos freqüentemente agmátíca), estruturas do tipo lavas almofadadas e encraves máfícos com formas irregulares. Contatos crenulados entre rochas máfícas e félsicas sugerem intensa difusão tônica. Elementos maiores e traços plotados contra sílica satisfazem o modelo de mistura de magmas, onde as rochas de composição híbrida plotam em posição intermediária entre máfícas e félsicas. Similaridade entre análises de microssonda eletrônica dos anfíbòlios dos encraves diorfticos potássicos do batólito de Itaporanga e os anfibólios do stock diorítíco potássico a leste do batólito sugere uma fonte comum para ambos os magmas. Esta hipótese é reforçada por padrões de elementos terras raras similares para os encraves diorfticos potássicos do batólito de Itaporanga e para o stock diorítíco potássico. O batólito possui uma foliação bem desenvolvida e que mergulha para o centro do plutão, sugerindo que o nível atual de afloramento representa a zona de raiz de um complexo diapfrico, na qual ocorreu intensa mistura entre magmas félsicos e máficos.
\end{abstract}

Palavras-chaves: Mistura de magmas, Pré-Cambriano, Ciclo Brasiliano.

\begin{abstract}
The Precambrian Cachoeirinha-Salgueiro Fold Belt (CSF) located in the western portion of the states of Pernambuco and Paraíba is intruded, in its northern portion, by several coarsely porphyritic potassic calc-alkalic .batholiths. These batholiths were syntectonicaly unplaced in relation to the Brasiliano cycle (=Pan-African) and are commonly associated with potassium diorites suggesting coexistence and mixing between felsic and mafic magmas. In the Itaporanga batholith three petrographic domains-were mapped. A hybrid zone characterized by intense mechanical mixing of granite to granodiorite and potassium diorite magmas is located towards the border of the batholith. A commingling zone where felsic porphyritic granite to granodiorite and potassium diorite rocks are individualized at outcrop scale is located towards the center of the batholith. Finally a felsic porphyritic fades occur in the hybrid zone. The intense mechanical mixing observed in the hybrid zone developed migmatite-like structures (stromatic and less frequently agmatic), pillov -like structures, mafic enclaves with irregular shape and cuspate contacts between mafic and felsic rocks, suggesting diffusion of chemical species across contact. Major and trace element plotted against $\mathrm{SiO}_{2}$ agree with a mixing model to explain the hybrid samples plotted at intermediate position between felsic and mafic rocks. Similarity among chemical analyses of amphiboles from potassium dioritic enclaves of the Itaporanga batholith and from the potassium diorite stock east of it suggest a common source for both magmas. This hypothesis is corroborated by similar REE patterns for potassium dioritic enclaves of the Itaporanga batholith and for the potassium diorite stock. The batholith shows a well developed foliation which dips towards its core suggesting that the present level of exposure represents the root zone of a diapir, where intense interaction between felsic and mafic magmas took place.
\end{abstract}

Keywords: Magma mixing. Late Precambrian, Brasiliano Cycle.

INTRODUCTION Plutonic rocks are very common in the Northeastern Brazil. The number of studies concerned with these rocks have increased considerably in the last five years, based on their importance in unraveling the tectonic history of the Brasiliano Cycle (400-700 Ma) (=PanAfrican), the last major tectono-thermal event to occur in the area.

The studied pluton is located in Northeastern Brazil, in the western portion of the state of Paraíba, in the Cachoeirinha-Salgueiro Fold Belt (CSF) (Sial 1986), also called Piancó-Alto Brigida system (Brito Neves 1975). The CSF is an ENE-trending belt located in the states of Pernambuco and Paraíba, with an area of approximately $20,000 \mathrm{~km}^{2}$ (Fig. 1). This Precambrian fold belt is composed of the Cachoeirinha and Salgueiro Groups (Barbosa 1970) and considered by some authors to represent different metamorphic fades of the same major lithologic unit (Santos et al. 1984).
Almeida et al. (1967) identified two main groups of granitoids in the northeastern region of Brazil, based on their textural, mineralogical and emplacement relationship to the Brasiliano Cycle:

a. synorogenic granitoid rocks - granodiorites, tonalites and calc-alkaline porphyritic granites regarded as the oldest granitoids in the area and called Conceição-type. They also included in this group granitic rocks with well developed porphyritic texture, with abundant microline megacrysts (up to $10 \mathrm{~cm}$ in length), named Itaporanga-type;

b. late erogenic granitic rocks - this group includes the Itapetim and Catingueira-types. The former, composed of biotite granites, is associated with the Itaporanga-type. The Catingueira type is represented by peralkaline rocks with alkali-rich pyroxene and amphibole. The authors included petrographic descriptions for the four granite types, but their work suffered from a total lack of geochemical data.

Sial et al. $(1981 \mathrm{a}, \mathrm{b})$ presented the first geochemical data 

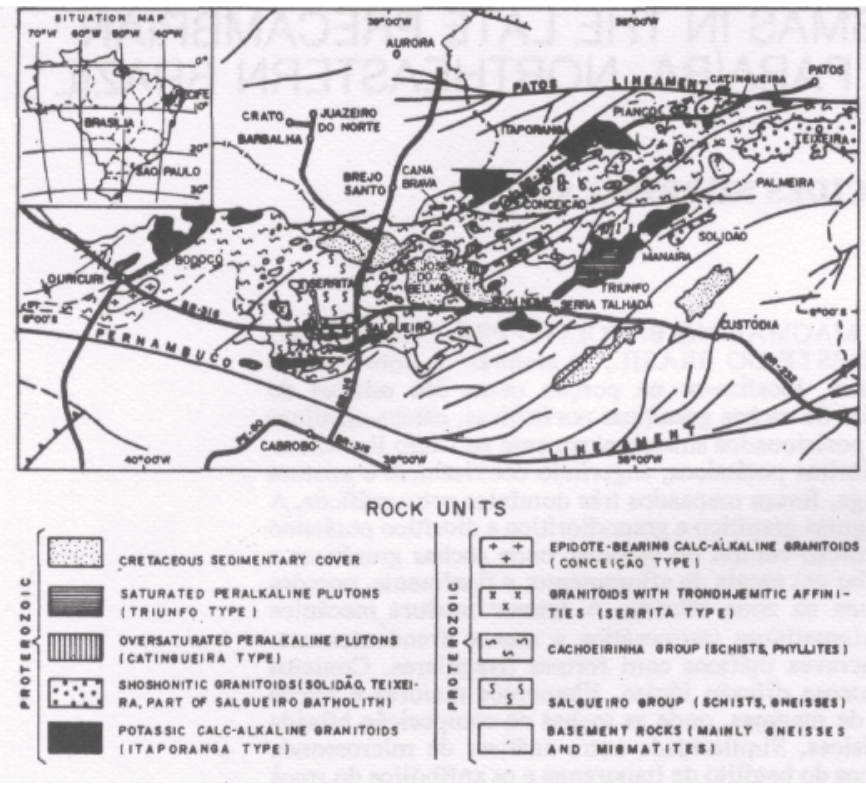

Figure $l$ - General geologic map of the CachoeirinhaSalgueiro Fold Belt showing the different granite types and the study area (modified from Sial \& Ferreira 1988) Figura 1 - Mapa geológico do cinturão de dobramentos CachoeirinhaSalgueiro mostrando os diferentes tipos de granitos e a área em estudo (modificado de Sial \& Ferreira 1988)

for the Bodocó batholith, equivalent to the Itaporanga-type of Almeida et al. (1967), and for two stocks near the town of Serrita, which were identified as of trondhjemitic affinities, both in the state of Pernambuco.

Sial $(1984 a, b)$ discussed rare earth element (REE) analyses and oxygen isotope data for several plutons in the CSF. He concluded that all of them showed highly fractionated REE patterns and that the oxygen isotopes together with whole rock chemistry and mineralogical compositon suggested the existence of four major groups (Fig. 1): a. Potassic calc-alkaline group - the same as the Itaporanga-type of Almeida et al. (1967) emplaced into the gneisses of the Serido Group in the northern and northwestern boundary of the CSF (Bodocó, Itaporanga, and Serra da Lagoinha batholiths). These granitic rocks are characterized by extremely porphyritic texture with microcline megacrysts up to $10 \mathrm{~cm}$ in length; b. Calc-alkaline group - the same as the Conceição-type of Almeida et al. (1967), characterized by magmatic epidote, and emplaced within the low grade metasediments of the CSF; c. Continental throndhjemitic group - composed of the Serrita stock and portions of the Salgueiro batholith intrusive into the schists of the Salgueiro Group; d. Peralkaline Group - the same as the Catingueira-type of Almeida et al. (1967), commonly occuring as large dikes near major fault zones.

Sial (1986, 1987) reviewed the granite types in Northeastern Brazil and summarized the current level of knowledge giving special attention to the CSF granitoids. He discussed chemical data including major and trace elements, REE, and oxygen isotopes.

The Itaporanga batholith area was included in the Cachoeirinha mapping project (Silva Filho 1985) in the scale of 1:100,000 and was classified as porphyritic monzonite and granite. Evaluation of potential mineral resources was the main purpose of that work and no geochemical data for most igneous rocks were presented. The Itaporanga map sheet published as a result of that work was the geologic base for the present study.
THE ITAPORANGA BATHOLITH The Itaporangatype granitoids have a widespread distribution in Northeastern Brazil, and are commonly found associated with biotite diorites (Sial et al. 1989). The Itaporanga batholith is composed of potassium diorite, monzodiorite, quartz monzonite, granodiorite and granite.

Several field evidences suggest interaction between potassium dioritic and granitic magmas as responsible for the observed lithologies. The most important features are: a. The igneous texture and mineralogy of the mafic enclaves, lacking minerals characteristic of S-type granitoids and pre-existent foliation; $b$. The presence of pillow-like structures (Photo 1) which suggest that the mafic magma quenched in contact with the felsic one, with growth of abundant acicular apatite in the former (Photo 2); c. The abundance of stromatic (Photo 3) and agmatic (Photo 4) structures and d. the irregular shape and cuspate contacts of the mafic enclaves, clearly evidencing interaction between liquids of contrasting chemical composition.

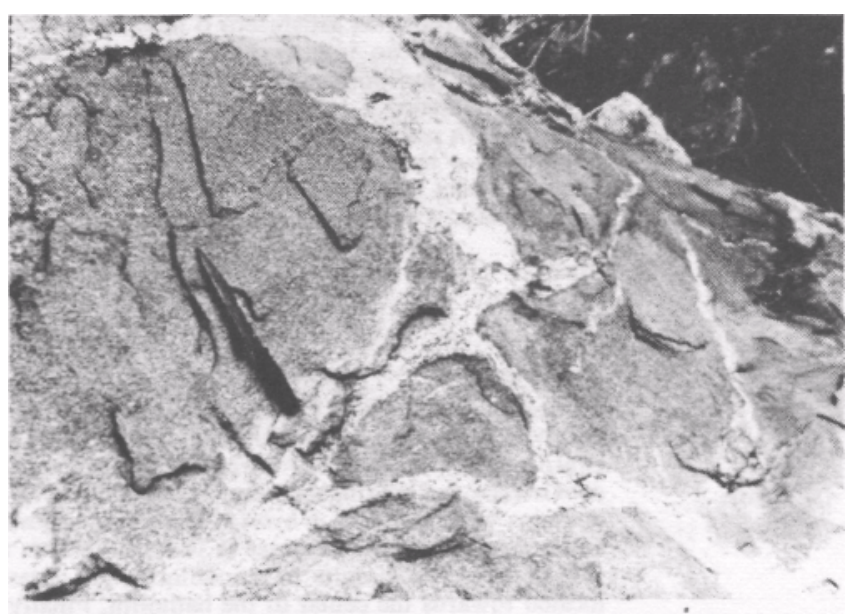

Photo 1 - Pillow-like structure developed by quenching of the potassium dioritic magma in contact with the porphyritic quartz monzonite to granite mush

Foto 1 - Estruturas tipo-lavas almofadadas, desenvolvidas pelo resfriamento do magma diorítico-potássico em contato com o "mush" quartzo monzonito a granito porfirftico

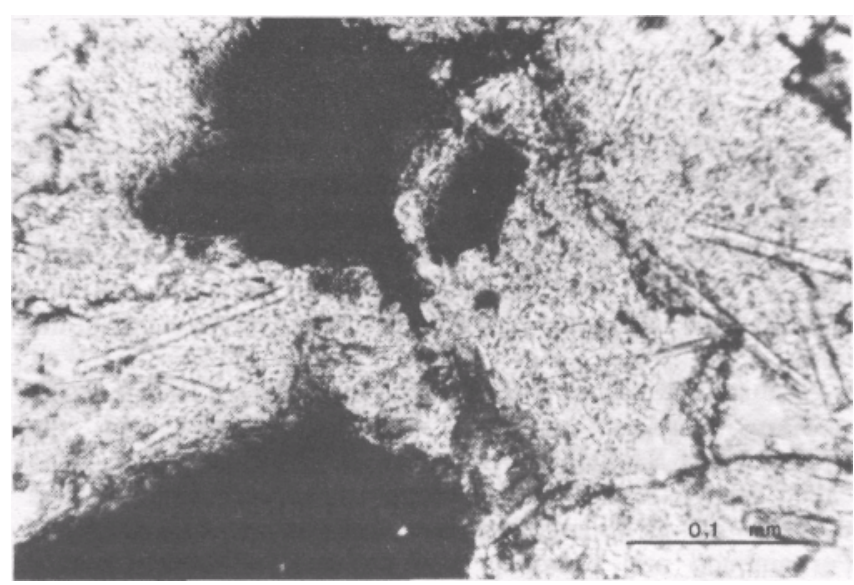

Photo 2 - Acicular apatite, common where the potassium diorite magma quenched against the porphyritic quartz monzonite to granite mush

Foto 2 - Apatita acicular, comum onde o magma diorítico potássico esfriou bruscamente em contato com o "mush" quartzo monzonito a granito porfirftico 


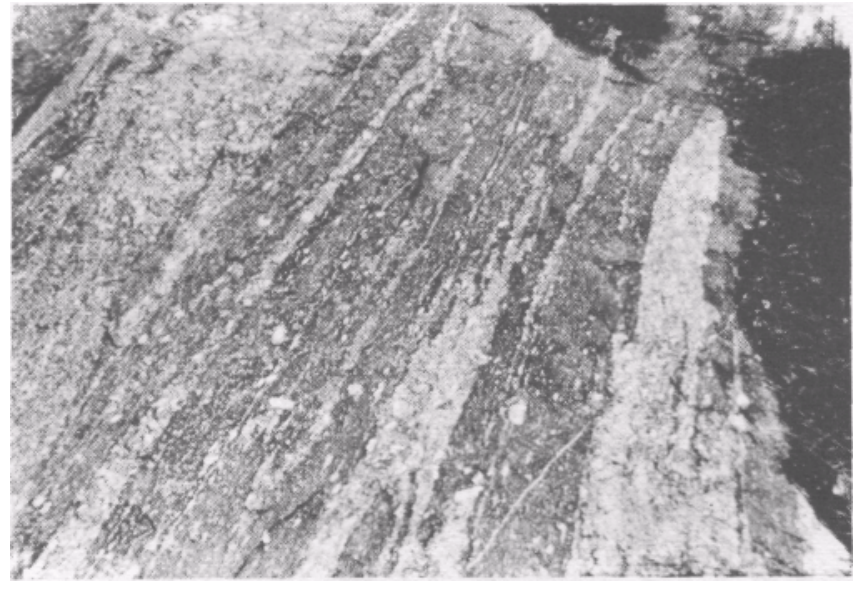

Photo 3 - Stromatic feature of the Itaporanga batholith. A common outcrop of the hybrid zone. Mafic rocks are essentially potassium diorites andfelsicporphyritic rocks vary from quartz monzonite to granodiorite. The irregular shape of the mafic enclaves suggests plastic deformation

Foto 3 - Estrutura estromátíca no batólito de Itaporanga. Um afloramento comum da zona híbrida. Rochas máficas são essencialmente dioritos potássicos, enquanto as rochas félsicas porfíríticas variam de quartzo monzonito a granodiorito. $\mathrm{O}$ formato irregular dos encraves máficos sugere deformação no estado plástico

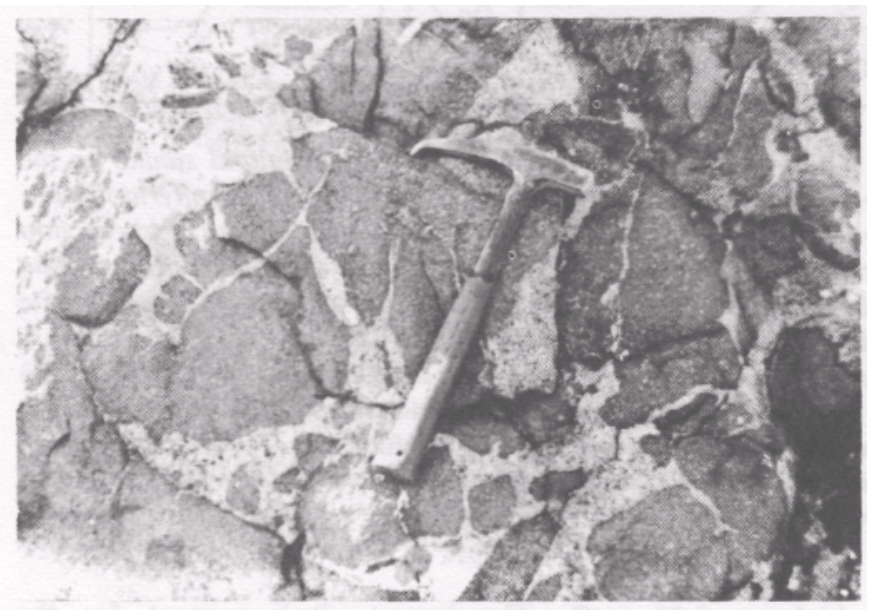

Photo 4 - Agmatic structure in the hybrid zone of the Itaporanga batholith. The subangular shape of the mafic portions suggests that the potassium diorite was almost completely crystallized during the interaction with the felsic magma

Foto 4 - Estrutura agmática na zona híbrida do Batólito de Itaporanga. A forma subangular das porções máficas sugere que o diorito potássico era quase totalmente sólido quando da interação com o magma félsico

The occurrence of potassium diorites as pillow-like structures, as dikes cutting through the felsic porphyritic rocks, and in agmatic structures, indicate more than one pulse of the mafic magma during the evolution of the Itaporanga batholith.

PETROGRAPHY Three domains are identified (Fig. 2): a. Hybrid zone - developed by alteration of mafic (potassium diorite) and felsic (granodiorite to granite) magmas, located towards the border of the batholith. Stromatic and agmatic structures are commonly observed (Photo 3 and 4 ). b. Porphyritic zone - represented by a curved elongated band throughout the batholith characterized by porphyritic quartz monzonite, granodiorite and granite, with potassium feldspar phenocrystals up to $10 \mathrm{~cm}$ in length. Eliptical enclaves of potassium diorite and schist xenoliths are commonly observed. Potassium feldspar concentrations are found as "rafts" several meters in lenght, probably representing cumulates, c. Commingling zone - located between the hybrid and porphyritic zones in the central northern and southern portions of the pluton, characterized by potassium dioritic portions up to few meters in lenght associated with porphyritic quartz monzonite to granite.

The porphyritic texture observed throughout the Itaporanga batholith difficults the obtention of representative samples and the use of modal analyses in thin sections. To overcome this limitation a chemical classification based on CIPW normative constituents (Streckeisen \& LeMaitre 1979) was uded (Fig. 3). Based on this classification, thin sections modal analyses of the mafic rocks and groudmass of the porphyritic rocks, and field relationships, the Itaporanga batholith can be divided into three main petrographic facies:

a. porphyritic quartz monzonite to granite - composed of potassium feldspar (microcline and occasional orthoclase), which ranges from Or80.2 to Or93.0 (Mariano 1989). It occurs as subhedral to anhedral megacrysts or in the groudmass $(0,6 \mathrm{~mm}$ to $30 \mathrm{~mm}$ in length), crystallized as orthoclase which inverted during cooling, showing permite (film, flame and patch) and less commonly anti-perthite. Plagioclase An 19-23 (Mariano 1989) occurs as phenocrysts, smaller and less abundant than the potassium feldspars, and in the groundmass $(0.75 \mathrm{~mm}$ to $4.0 \mathrm{~mm}$ in length) where it is the major feldspar. Most of the crystals show variable degree of serialization, commonly concentrated in the crystal core, biotite and apatite inclusions, and are zoned.

Biotite usually occurs as small flakes $(0.22 \mathrm{~mm}$ to $4.0 \mathrm{~mm}$ in length) filling interstices between potassium feldspars, plagioclases and hornblendes, or as inclusions in these minerals. Quartz shows ondulose extinction, subgrain formation, varying in length from $0.22 \mathrm{~mm}$ to $4.0 \mathrm{~mm}$.

Amphibole is classified according to Leake (1978) as varying from ferroedenite to edenite (Mariano 1989). It commonly occurs as anhedral to subhedral twinned crystals $(0.22 \mathrm{~mm}$ to $5.0 \mathrm{~mm})$ or as small inclusions in feldspars. Sphene, as large anhedral crystals $(0.20 \mathrm{~mm}$ to $6.0 \mathrm{~mm}$ in length), is the most common accessory phase, associated with biotite and hornblende. Apatite occurs as small stubby prisms, commonly as inclusions in plagioclase. Allanite occurs as anhedral, prismatic, zoned crystals, with corroded cores, locally surrounded by epidote. Zircon is found as inclusions in biotite, but occasional, isolated crystals are seen. Secondary epidote (sausuritization) is commom where deformation is more pronounced. Sericite and calcite are alteration products of feldspars.

b. Monzonite to granodiorite - texturally and mineralogically similar to the porphyritic facies, more common towards the edge of the batholith, in the area mapped as hybrid zone.

The petrographic types are the same as those of the porphyritic facies, except for the presence of common acicular apatite and occasional opaque minerals associated with biotite, titanite, and/or hornblende.

c. Monzodiorite to potassium diorite - occurs in the hybrid and commingling zones, having the same mineral phases mentioned above plus abundant acicular apatite with length/width ratio up to 20 included in all phases (Photo 2), and plagioclase crystals, more calcic in composition, showing corroded borders and irregular zoning patterns (patchy zoning). A common feature of this zone is the enrichment in biotite and amphibole compared to the above mentioned zones. The microprobe analyses of amphibole in the mafic enclaves showed them to be chemically similar to the host 


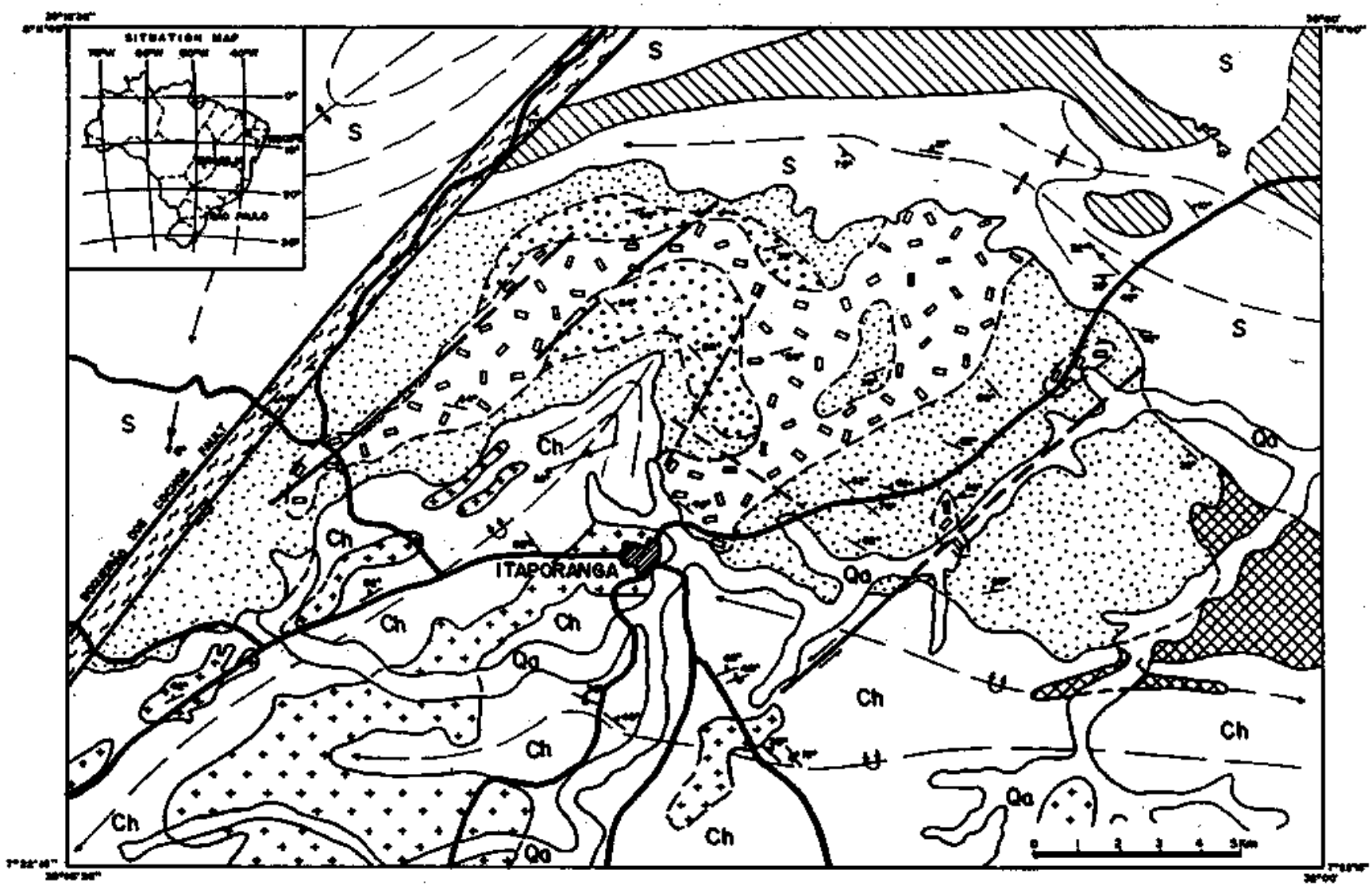

Figure 2 - Geologic map of the Itaporanga bathotith area: Qa - Quaternary alluvial deposits: (+ + +) granitoid similar to the Conceição-type granitoids: (II) granitoid similar to the Serrita-type granitoids; Itaporangaphtton ( $\left.{ }_{\Pi}\right)$ felsicporphyritic zone quartz monzonite to graftite (with potassium feldspar megacrysts up to $10 \mathrm{~cm}$ in length); (...) hybrid zone - high degree of interaction between monzodioritic, monzonitic and granitic magmas; $(\bullet \bullet)$ commingling zone -diorite to monzodiorite and porphyritic granite to quartz monzonite individualized at outcrop scale; Ch - Cachoeirinha Group (phylKtes, schists, biotite schists and garnet-biotite schists); $S$ - Sendo Grou\$(amphibolites and gneisses, showing interlayering), (modified from Silva Filho 1985) Figura 2 - Mapa geológico do Batòlito de Itaporanga: Qa - depósitos aluvionares quaternários; $(+++)$ Granitóides semelhantes ao típo-Conceiçã o; (III) Granitóides semelhantes ao tipo Serrita; $O$ batólito de Itaporanga - $\left({ }_{\Pi}\right)$ granito porfirítíco (megacristais de féldspato potássico com até $10 \mathrm{~cm}$ de comprimento); (...) zona híbrida caracterizada por intensa interação entre magmas monzodiorítico, monzonftico e granftíco; (•・•) zona de commingling - diorito a monzodiorito e granito porfírítico individualizados em escala de afloramento; Ch - Grupo Cachoeirinha (filitos, xistos, biotíta xistos e granada-biotita xistos); S - Grupo Seridó (anfíbolitos e gnaisses mostrando intercalaçõ es). Modificado de Silva Filho (1985)

rock amphibole, except for one enclave whose amphibole composition is identical to the amphiboles in the potassium diorite stock east of the Itaporanga batholith (Mariano 1989). Clinopyroxene (diopside) in the mafic enclaves commonly underwent partial replacement by amphibole (actionolitic hornblende).

GEOCHEMISTRY OF THE ITAPORANGA BATHOLITH Twenty-eight samples of the Itaporanga batholith were selected for bulk chemical analyses of major and trace elements, covering the different lithologic fades. The chemical analyses were performed by GEOSOL laboratory, Belo Horizonte, state of Minas Gerais, Brazil, by $\mathrm{X}$-ray fluorescence, atomic absorption, and optical spectrometry techniques. REE were analysed by induced coupled plasma spectroscopy (ICP), according to the techniques described by Dutra (1984).

MAJOR ELEMENT GEOCHEMISTRY Most of the samples analysed were metaluminous, except for seven, which were peraluminous. The peraluminous rocks represented the mafic portion (potassium diorite) and porphyritic quartz monzonite from the hybrid zone, with normative corundum as high as $3.38 \mathrm{wt} \%$. The lowest alkali content for the Itaporanga batholith is found in these rocks $\left(\mathrm{Na}_{2} \mathrm{O}+\mathrm{K}_{2}=\right.$ $5.8 \mathrm{wt} \%)$. Some of the mafic and hybrid samples have normative ne due to their relative silic depletion and abundant $\mathrm{Na}_{2} \mathrm{O}$ (up to $5.2 \mathrm{wt} \%$ ).

Major element oxides plotted against $\mathrm{SiO}_{2}$ (Marker variation diagrams) show near linear trends with correlation coefficient varying from 0.06 to 0.92 . The porphyritic quartz monzonite to granite and the monzodiorite to diorite samples show to be reasonable endmembers for the hybrid rocks which vary from monzodiorite to granodiorite (Fig. 4). A high degree of scatter is show by $\mathrm{A}_{2} \mathrm{O}_{3}, \mathrm{~K}_{2} \mathrm{O}$ and $\mathrm{Na}_{2} \mathrm{O}$ due to local variation in microcline and plagioclase abundances. Figure 4 shows that mafic endmembers are strongly enriched in $\mathrm{TiO}_{2}, \mathrm{FeO}_{\mathrm{t}}, \mathrm{P}_{2} \mathrm{O}_{5}, \mathrm{CaO}$, and $\mathrm{MgO}$ compared to the felsic and hybrid samples.

The total alkali silica (TAS) diagram (Fig. 5) shows the subaOcaline character of the batholith and the enrichment in alkalies and silica towards the felsic endmember. Some samples plotted on the alkaline side of the diagram evidencing their alkali $(\mathrm{Na}, \mathrm{K})$ rich nature. This diagram also shows the felsic and mafic rocks as reasonable endmembers for the hybrid compositions. 


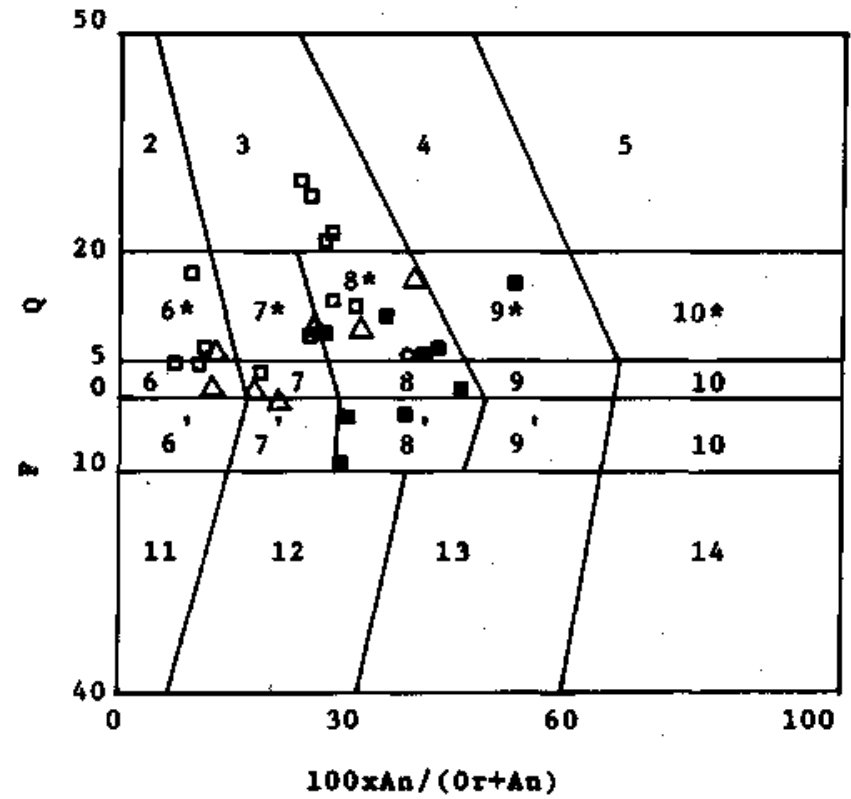

Figure 3 - Rock classification diagram based on normative constituents (Streckeisen \& LeMaitre 1979). Symbols represent lithologic domains: (ロ) mafic - monzodiorite do diorite; (4) hybrid - porphyritic monzonite to granodiorite; and () felsic porphyritic quartz monzonite to granite; $(O)$ small potassium diorite pluton. $100 \mathrm{q} /(q+o r+t a b+a n)$ and $F=100$ $(n e+l c+k p) /(n e+l c+k p+o r+a b+a n)$. Fields are: 2. alkali feldspar granite; 3. granite; 4. granodiorite; 5. tonalite; $6 *$. alkali-feldspar qz .syenite; $7^{*}$. qz syenite; $8^{*}$. qz monzonite; $9^{*}$. $q z$ monzodiorite An $<50$ / $q z$ monzogabbro An>50; $10^{*}$. $q z$ diorite/gabbro/anorthosite; 6. alkali feldspar syenite; 7. syenite; 8. monzonite; 9. monzodiorite/monzogabbro; 10. diorite/gabbro/anorthosite; 6'. fold bearing alkali-feldspar syenite; T. fold bearing syenite; V.foid bearing monzonite; 9'. foid bearing monzodiorite/monzogabbro; 10'. foid bearing diorite/gabbro; 11. foid syenite; 12.foidmonzosyenite; 13. foid monzodiorite/monzogabbro; 14 . foid diorite/gabbro Figura 3 - Diagrama para classificação de rochas baseado na sua composição normativa (Streckeisen \& LeMaitre 1979). A simbologia representa domínios litològicos: (ロ) Máfico - monzodiorito a diorito, (A)Hfbrido - monzonito a granodiorito porfírftíco e ( $\square$ ) Félsico - quartzo monzonito a granito porfirííco, (O) stock diorftico potássico. $\mathrm{Q}=100 \mathrm{q} /(\mathrm{q}+$ or $+\mathrm{ab}+\mathrm{an})$ e $\mathrm{F}^{\prime}=100 \quad(\mathrm{ne}+\mathrm{lc}+\mathrm{kpV}$ (ne+lc+kp+or+ab+an). Os campos do diagrama são: 2 . álcali-feldspato granito, 3. granito, 4. granodiorito; 5. tonalito, $6^{*}$. álcali-feldspato quartzo sienito, $7 *$. quartzo sienito, $8^{*}$. quartzo monzonito, 9*. quartzo monzodiorito/quartzo monzogabro, 10*. quartzo diorito/gabro/anortosito; 6. álcali feldspato sienito; 7. sienito; 8 . monzonito; 9. monzodiorito/monzogabro; 10. diorito/gabro/anortosito; 6'. álcali feldspato sienito com feldspatóide; 7 '. sienito com feldspatóide; 8'. monzonito com feldspatóide; 9'. monzodiorito/monzogabro com feldspatóide; 10. diorito/gabro com feldspatóide; 11. sienito com feldspatóide; 12. monzosienito com feldspatóide; 13. monzodiorito/monzogabro com feldspatóide; 14. diorito/gabro com feldspatóide

The calc-alkaline character of the rocks that compose the Itaporanga batholith is illustred in the AFM plot (Fig. 6). The hybrid samples plot at intermediate positions between felsic and mafic ones.

In the R1-R2 multicationic diagram (Batchelor \& Bowden 1985), most of the samples plot in the late erogenic field, with a few plotting in the post-collision uplift field (Fig. 7). The late orogenic field in the R1-R2 diagrams is also called subalkaline monzonitic trend. The distribution of samples shows spreading along the Rl (4Si-11( $\mathrm{Na}+\mathrm{K})-2(\mathrm{Fe}+\mathrm{Ti})$ ) axis which characterizes the strong influence of feldspar on alkali concentrations.

TRACE ELEMENT GEOCHEMISTRY Selected trace element ( $\mathrm{Rb}, \mathrm{Sr}, \mathrm{Ba}, \mathrm{Nb}$, and $\mathrm{Y}$ ) were analysed from the same rocks from which major elemens were determined.

Figure 8 shows trace element plotted against $\mathrm{SiO}_{2}$. Contrary to near linear pattern observed for most major elements, except for Sr, the trace elements show strong scatter (correlation coefficient varying from 0.18 to 0.53 ). Sr shows a near linear trend with the hybrid samples plotted at intermediate positions between the mafic and the felsic ones. The scattered trace element plots may be explained by variation in the mechanically and diffusionally controlled mixing between coexistent fractionated magmas, and the difficulty in obtaining representative samples. The scatter of these diagrams suggests that simple crystal fractionation did not play a major hole in the formation of the present lithologies, or that the mixing event erased previous crystal fractionation signature.

Primordial mantle normalized trace element plot (Fig. 9) shows enrichment in $\mathrm{Rb}, \mathrm{Ba}, \mathrm{K}, \mathrm{La}, \mathrm{Ce}, \mathrm{Nd}, \mathrm{Sr}$, and $\mathrm{Zr}$ relative to $\mathrm{Nb}, \mathrm{P}, \mathrm{Ti}$, and $\mathrm{Y}$. The diagram shows a strong negative slope also observed in all calc-alkaline plutons in the $\mathrm{CSF}$ and interpreted to represent a source inherited feature (Sial et al. 1989). The pattern shown by the Itaporanga batholith place it in the field of normal calc-alkaline continental arc granitoids of Brown et al. (1984).

Chondrite normalized trace element plot (Fig. 10) shows depletion in $\mathrm{Nb}, \mathrm{P}, \mathrm{Ti}$, and $\mathrm{Y}$ and enrichment in the other elements plotted. This diagram also shows a strong negative slope despite the accentuated $\mathrm{Zr}$ positive anomaly. Figures 9 and 10 share several common characteristics: a. strong negative slopes; $b$. negative anomaly of $\mathrm{P}$, with the felsic component being the most depleted; c. negative $\mathrm{Nb}$ anomaly; and $\mathrm{d}$. positive $\mathrm{Zr}$ anomaly relative to elements of similar compatibility. The mafic member is usually enriched in $P$, and where quench took place the mafic rock has abundant acicular apatite.

Ratio-ratio plot of $\mathrm{Ti} / \mathrm{Zr}$ versus $\mathrm{Rb} / \mathrm{Sr}$ (Fig. 11) shows a near hyperbolic distribution with the hybrid samples plotted at an intermediate position between the felsic and mafic ones. The hyperbola was calculated based on the two widely separated samples following Cox etal. (1979) suggestion, and not as a best fit line. The scatter form of a hyperbolic curve may be due to crystal fractionation prior to and/or during mixing of magmas as well as to difficulties in obtaining representative samples.

Vogel et al. (1987) suggest that to test mixing a companion plot in which the denominators of both ratios are the same should give a straight line. Figure 12, the companion plot of figure 11, shows near linear distribution. The scatter from a linear distribution is characterized by the spreading along the $\mathrm{Sr} / \mathrm{Zr}$ axis which is essentially controlled by variation in the relative abundance of microcline megacrysts.

RARE EARTH ELEMENT GEOCHEMISTRY Seven samples of the Itaporanga batholith were analysed for REE; one additional REE analysis was performed for the K-diorite body intruded along the eastern margin of the Itaporanga pluton.

Figure 13 is the chondrite normalized plot of three samples from the same outcrop in the hybrid zone, representing hybrid, mafic and felsic rocks. They have a strong enrichment in the LREE in relation to HREE with a steep negative slope pattern. The felsic porphyritic rock shows a positive Eu anomaly $\left(\mathrm{Eu} / \mathrm{Eu}^{*}=1.5\right)$, while the hybrid and mafic samples lack Eu anomaly. The hybrid sample is enriched in LREE 


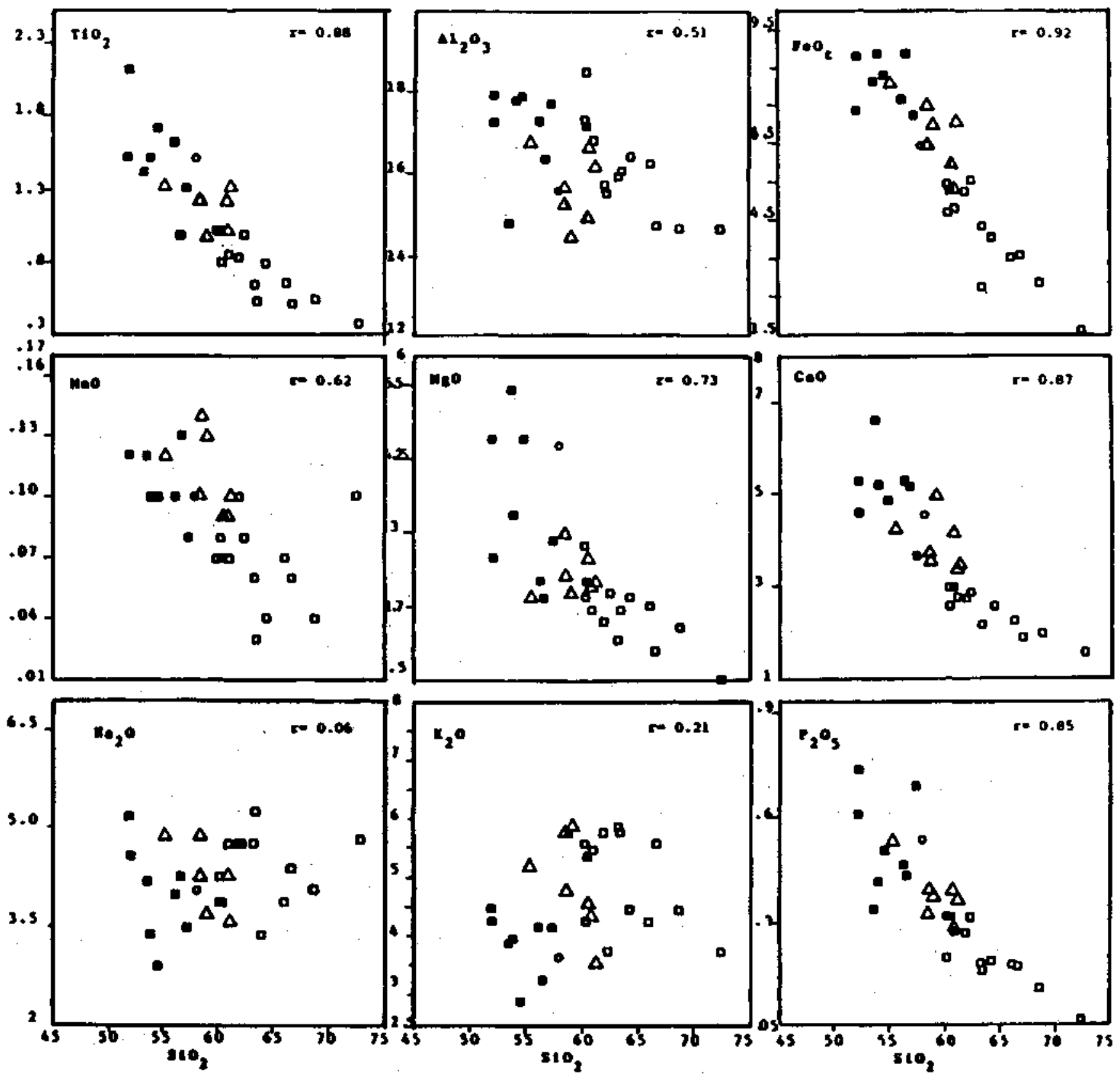

Flgure 4-Major axides plotted against $\mathrm{SHO}_{2}$. Symbols as in figture 3

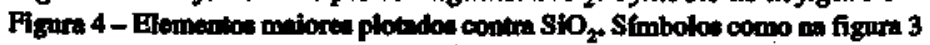

relative to the felsic and mafic ones, and plot at intermediate position for the HREE.

The potassium diorite stock in contact with the eastern side of the Itaporanga pluton shows a REE pattern similar to those ones observed for the Itaporanga rocks (Fig. 14).

The small positive Eu anomaly of some of the felsic porphyritic samples may be caused by the high modal proportion of feldspar in these rocks (up to $70 \%$ by volume) and low abundance of amphibole. The enrichment in the REE in the hybrid samples is probably due to the higher concentration of amphibole, sphene and zircon in these rocks, once accessory phases such as sphene and allanite have strong control on the REE pattern of calc-alkaline rocks since they contain up to $80 \%$ of the REE of these rocks (Gromet \& Silver 1983).

The REE pattern for the mafic component of the Itaporanga pluton is similar to that one obtained for the biotite diorite to the east of the pluton. They are enriched in HREE relative to the felsic and hybrid rocks, which may be explained by higher proportion of hornblende in these rocks (up to $15 \%$ by volume).

The chondrite normalized plots of the Itaporanga pluton show several common characteristics: LREE enrichment relative to HREE, negligible to absent Eu anomalies, and steep negative slope (highly fractionated pattern) which are observed in most granitoids of this type in the CSF (Sial 1984b).

The LREE enrichment relative to HREE-common to all lithologies in the Itaporanga batholith and also observed in the biotite diorite stock emplaced to the east of the pluton-reflects a source controlled pattern.

DISCUSSION AND CONCLUSIONS Magma mixing, fractional crystallization and country rock assimilation are 


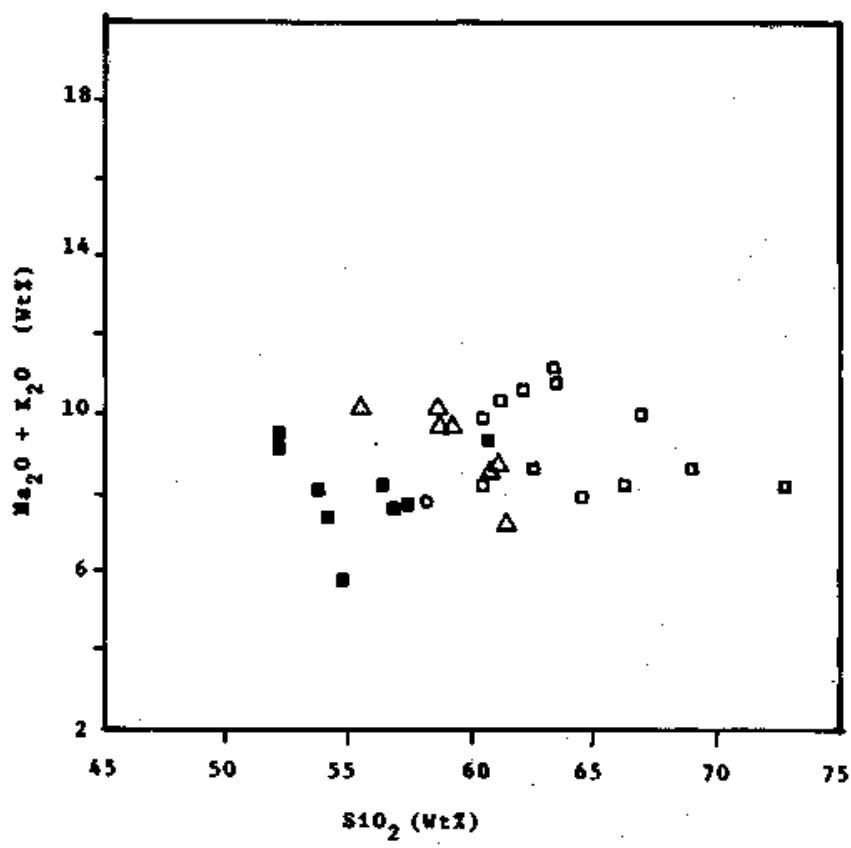

Figure 5 - Total alkali silica -(TAS) diagram. Alkaline and subalkaline fields according to Irvine \& Baragar (1971). Symbols as in figure 3

Figura 5 - Diagrama de álcalis totais versus silica. Campos das rochas alcalinas e subalcalinas de acordo com Irvine \& Baragar (1971). Símbolos como na figura 3

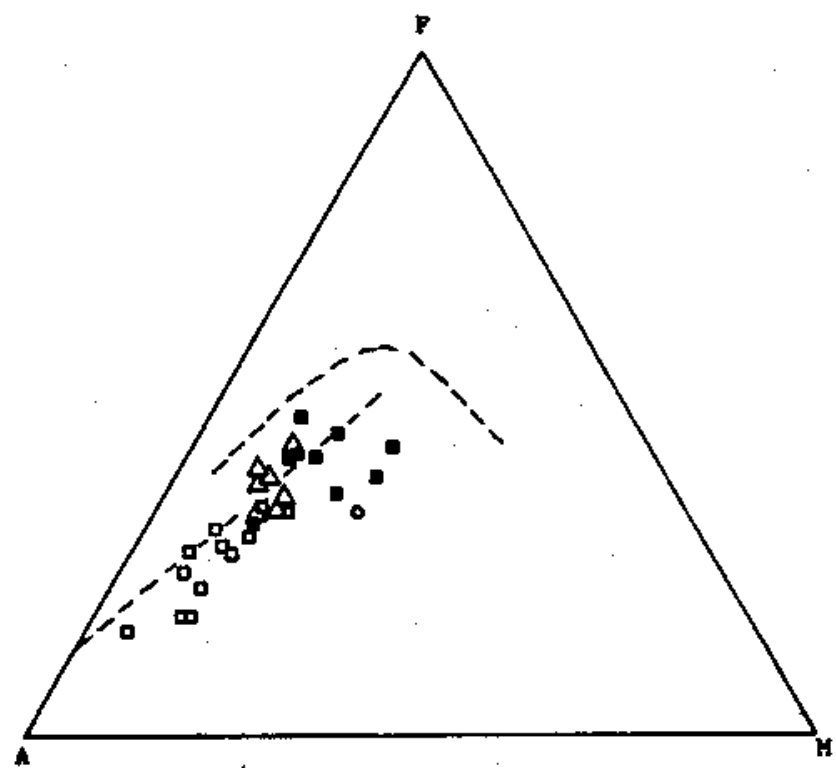

Figure 6 - AFM ternary plot. Dashed line is the mixing line of Kialineq hybrid (after Brooks 1977). Tholeitic and calc-alkaline fields accordinge to Irvine \& Baragar (1971). Symbols as in figure 3

Figura 6 - Diagrama AFM. Linha tracejada e a linha de mistura das rochas híbridas de Kialineq (Brooks 1977). Campos das rochas tolefticas e cálcio-alcalinas de acordo com Irvine \& Baragar (1971). Símbolos como na figura 3

important processes involved during chemical evolution of granitic melts. They usually vary in importance for evolutionary history of specific plutons (e. g. Brown \& Becker 1986. Wiebe \& Wild 1983, Ferrara et al. 1986, Dorais 1987, Reid \& Hamilton 1987, and Cook 1988).

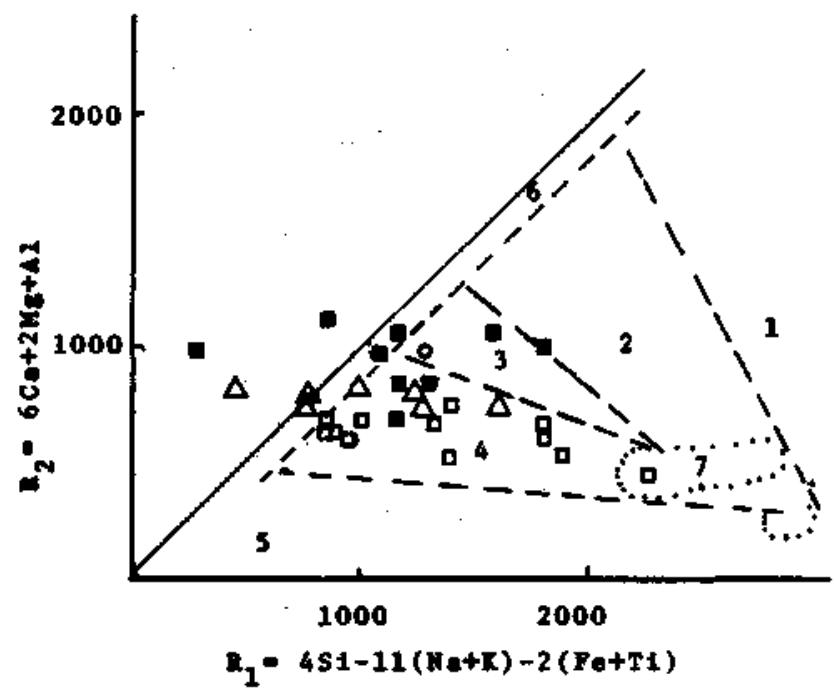

Figure 7 - Multicationic diagram $R_{1} R_{2}$ (after Batchelar \& Bowden 1985). Symbols as in figure 7. Fields are: 1. mantle fractionates (tholeütic group), 2. pre-plate collision (calc-aVcaline and trondhjemitic group), 3. post-collision uplift (high potassic calc-alkaline group), 4. Late orogenic (sub-alkaline monzonitic group), 5. Anorogenic (alkaline and peralkaline group); 6. Source trend, through an orogenic cycle; and 7. syn-coltision (anatectic 2-mica leucogranites) Figura 7 - Diagrama multícatidnico R., R (Batcbelor \& Bowden 1985). Símbolos como na Figura 7. Os campos sio: 1. material frackmado do manto (grupo toleítíco); 2. pré-colisio entre placas (grupo cálcio-alcalino e trondhjemftíco); 3. Soerguimento pós-colisáo (grupo cálcio-alcalino rico em potássio); 4. tardi-orogenético (grupo sub-alcalino monzonítíco); 5. anorogênico (grupo alcalino e peralcalino); 6. trend através de um ciclo orogeoético; 7. sincolisão (granitos anateücos com duas micas)

The Itaporanga magma started crystallizing amphibole at a depth of at least $15 \mathrm{~km}-18 \mathrm{~km}$ (Mariano et al. in press). Crystal fractionation and, to a negligible extent, country rock assimilation are processes involved in the Itaporanga pluton petrogenesis, but the field evidence for magma mixing suggests that this process best explains the lithologic association found in this diapirically emplaced batholith.

Vogel et al. (1984) discuss magma mixing for the Marsco suite, Scotlang, emphasizing that viscosity and temperature differences are the most important obstacles to mixing. The emplacement of the Itaporanga batholith during a major tectono-thermal event (shear-related event) enhanced mechanical mixing between the commingled magmas, increasing surface interaction, supressing viscosity and temperature contrasts, and promoting lithologic gradation from diorite to granite. The intensity of the mechanical mixing is illustrated by abundant migmatite-like features (stromatic and agmatic structures, Mehnert 1968) in the hybrid zone (Photos 3 and 4).

Whalen \& Cume (1984) suggest shearing as the only process capable of large scale homogenization of coexistent magmas of contrasting compositions, compared to bouyant (Huppert et al. 1983) and forced convection (Kouchi \& Sunagawa 1983).

The occurrence of pillow-like structures and potassium diorite brecciated by quartz monzonite suggest incomplete mixing. On the other hand cuspate contacts betweer the felsic and mafic rocks indicate their interaction with considerable proportion of liquid, and significant diffusion along boundaries (Photos 1, 2 and 4). All the pillow-like structures and most of the mafic enclaves show acicular apatite with 


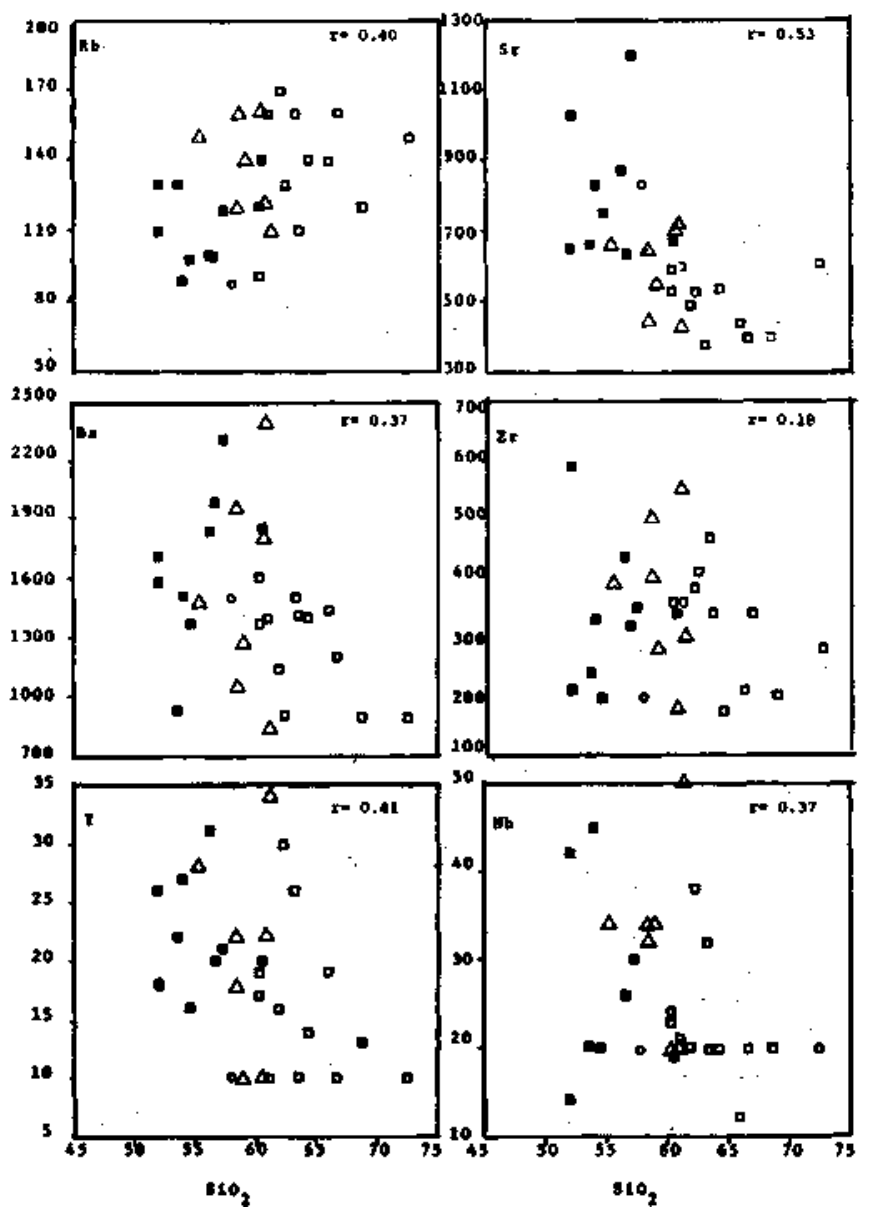

Figure 8 - Trace elements plotted against $\mathrm{Si}_{2}$. Symbols as in figure 3

Figura 8 - Elementos traços plotados contra $\mathrm{SiO}_{2}$. Símbolos como na figura 3

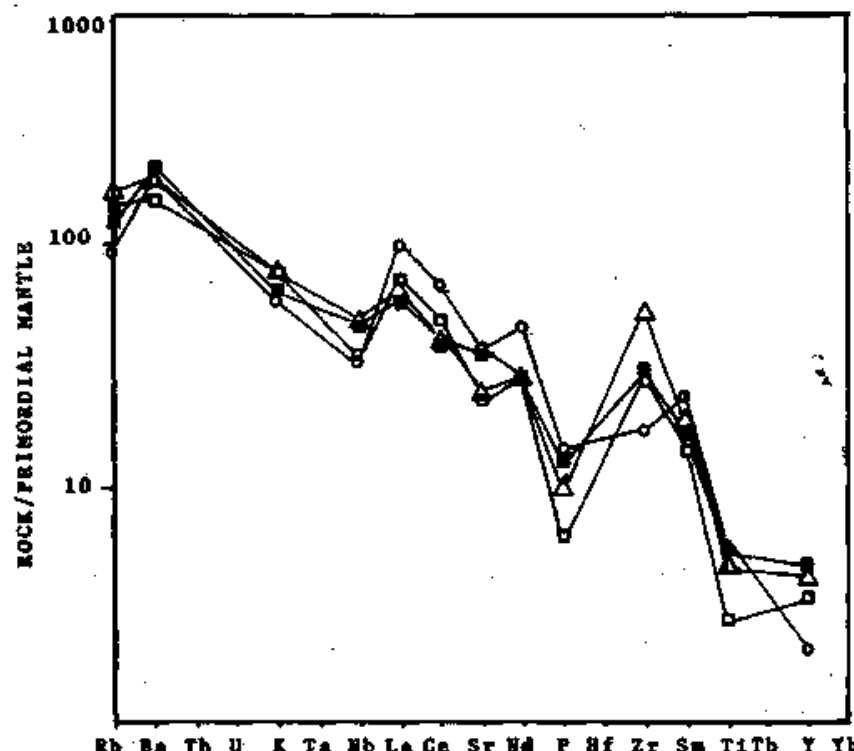

Figure 9 - Primordial mantle normalized trace element diagram. Normalizing factors from Wood (1979). Symbols as in figure 3

Figura 9 - Diagrama de elementos traços normalizados por manto primitivo. Fator de normalização de Wood (1979). Símbolos como na figura 3

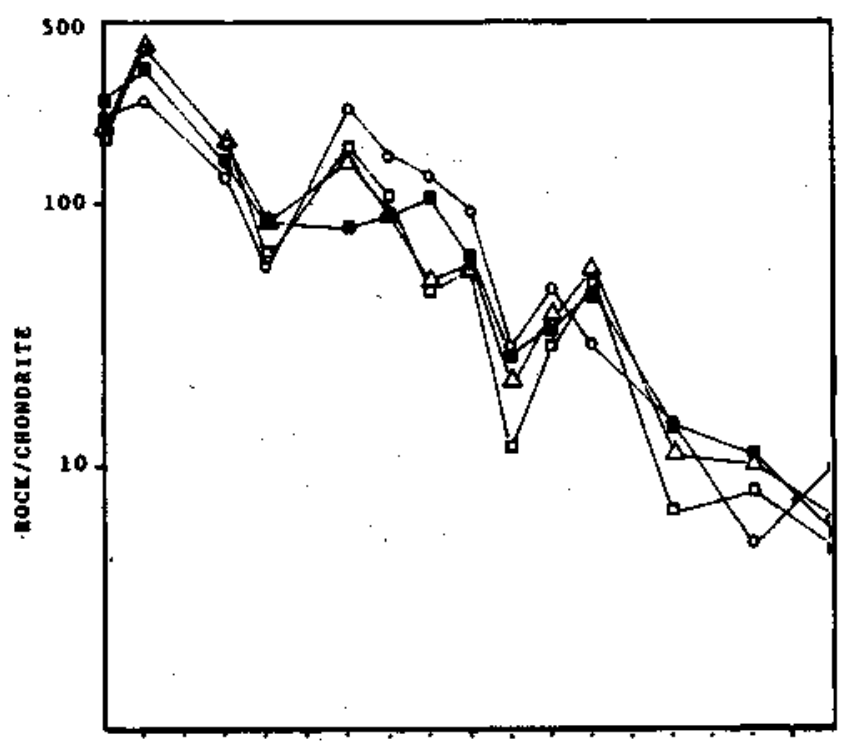

Ba Rb Th K Nb Ta La Ce Sr Nd P S* Zr Hf Ti Tb Y T» Y

Figure 10 - Chondrite normalized trace element diagram. Normalizing factors from Thompson et al. (1983). Symbols as in figure 3

Figura 10 - Diagrama de elementos traços normalizados por coodrito. Fator de normalização de Thompson et al. (1983). Símbolos como na figura 3

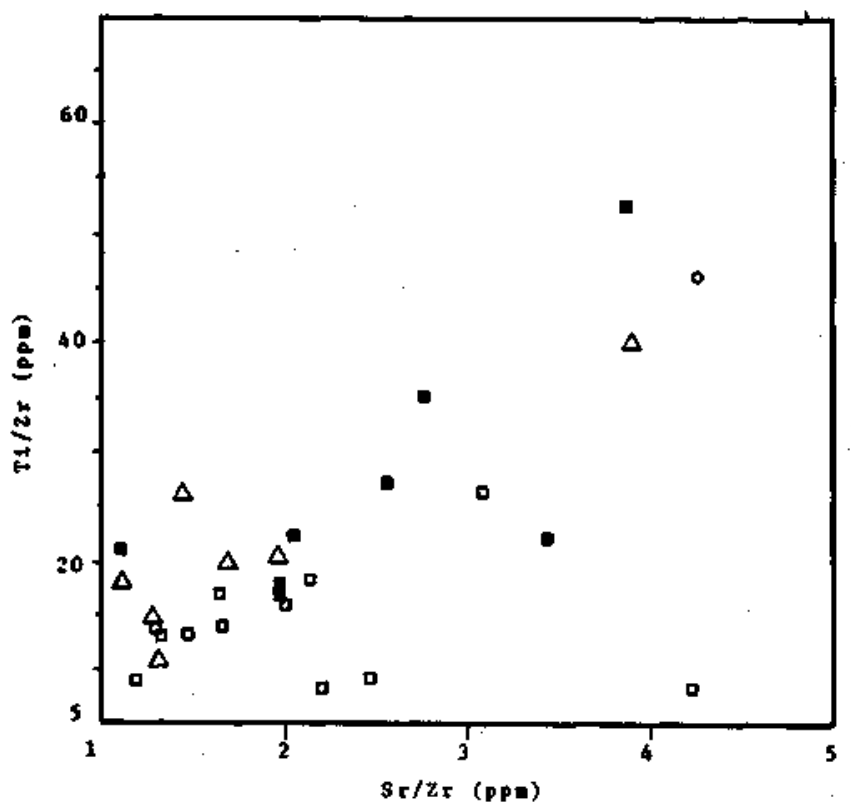

Figure 11 - Ratio-ratio trace element diagram (Ti/Zr versus $\mathrm{Rb} / \mathrm{Sr}$ ). Symbols as in figure 3

Figura 11 - Diagrama razão/razão com elementos traços, ( $\mathrm{Ti} / \mathrm{Zr}$ versus $\mathrm{Rh} / \mathrm{Sr}$ ). Símbolos como na figura 3

length/width of approximately 20 , suggestive of quenching.

The diffusion of chemical species along contacts between felsic and mafic magmas is responsible for the chemical equilibrium between mineral phases in mafic enclaves and host rocks. Probe data for hornblende from felsic rocks, mafic enclaves and rocks with pillow-like shape show similar composition except for one enclave which showed amphibole compositions identical to that obtained for the potassium diorite stock east of the Itaporanga batholith. The amphibole 


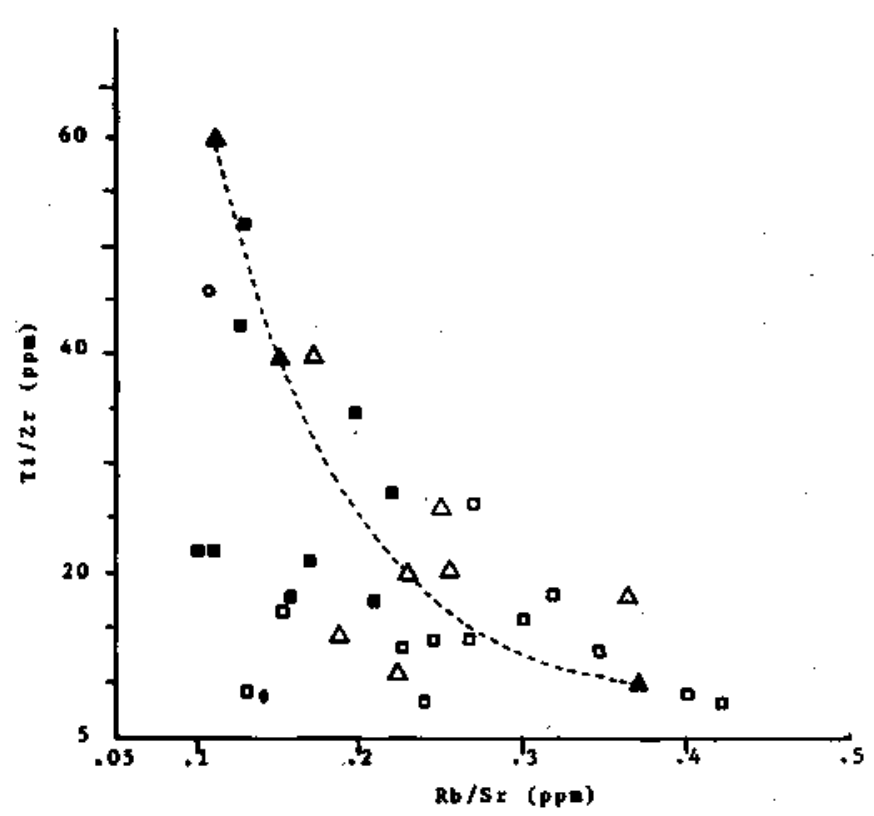

Figure 12 - Ratio-ratio trace element diagram (Ti/Zr versus Sr/Zr). Symbols as in figure 3

Figura 12 - Diagrama razão/razão com elementos traços (Ti/Zr versus $\mathrm{Sr} / \mathrm{Zr}$ ). Símbolos como na figura 3

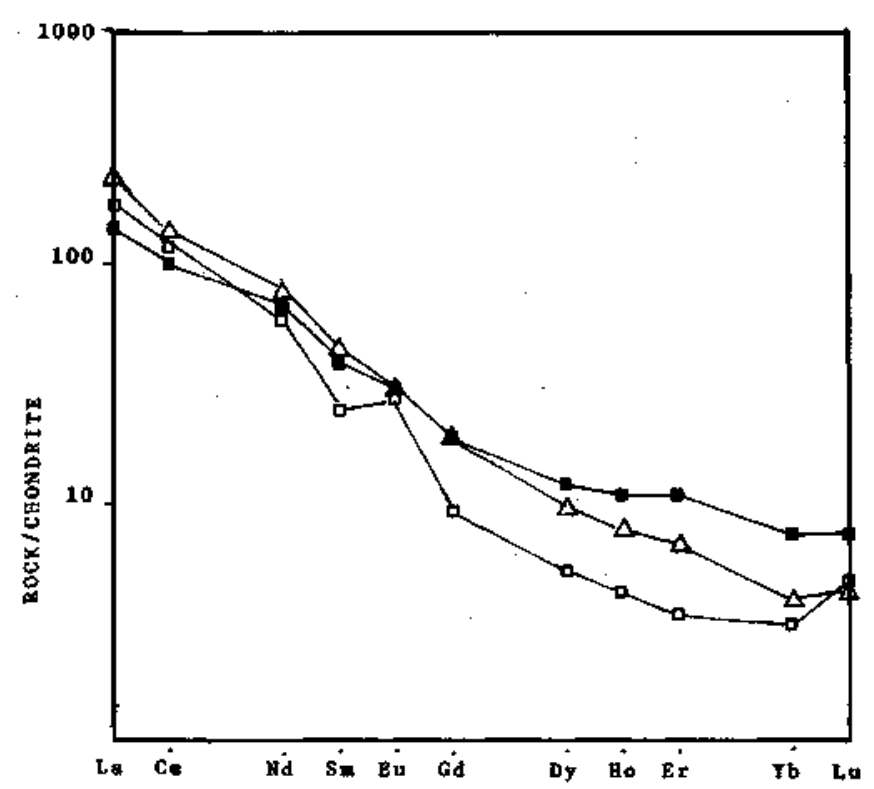

Figure 13 - Chondrite normalized REE diagram, showing the felsic hybrid and mafic fades of the liaporanga batholith from the same outcrop. Normalizing factors from Evensen et al. (1978). Symbols represent lithologic domains: (ロ) mafic monzodiorite to diorite; (AJ hybrid - porphyritic monzonite to granodiorite; and () felsic - porphyritic quartz monzonite to granite

Figura 13 - Diagrama de elementos terras raras normalizados por condrito, mostrando as fácies félsica, híbrida e máfica do Batólito de Itaporanga. Fatores de normalização de Evensen et al. (1978). Símbolos representam domínios litológicos; (匹) máfíco - monzodiorito a diorito; $(\Delta)$ híbrido - monzonito a granodiorito porfirftico; (D) félsico - quartzo monzonito a granito porfirftico

of this enclave probably failed to reequilibrate with the host rock and is the strongest evidence to support the hypothesis that the potassium diorite magma and the mafic magma that

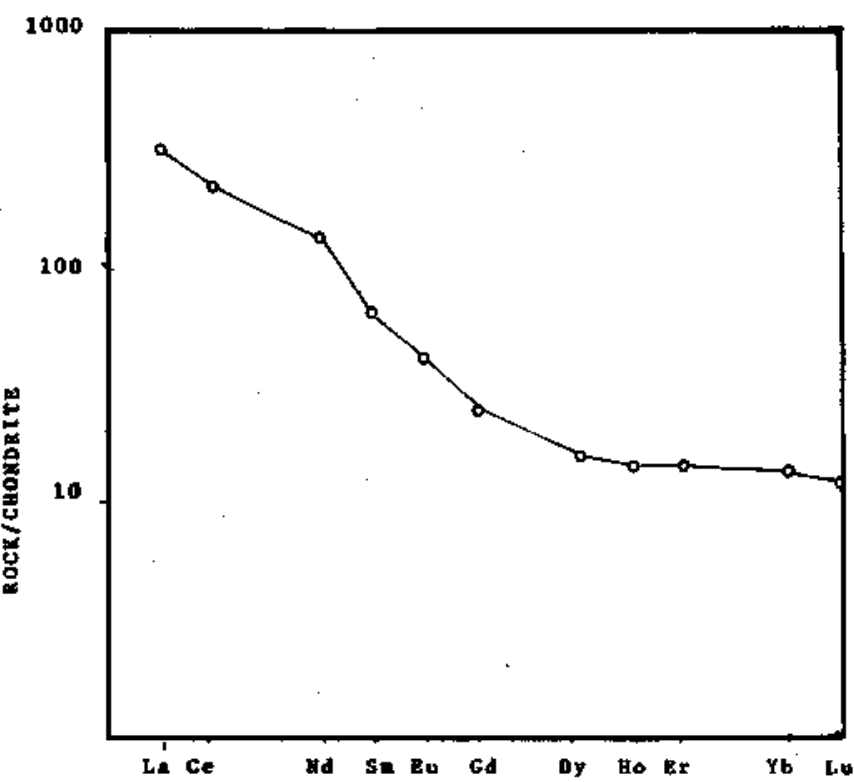

Figure 14 - Chondrite normalized REE diagram for the potassium diorite pluton east of the Itaporanga batholith. Normalizing values from Evensen et al. (1978) Figura 14 - Diagrama de terras raras normalizados por condrito para o stock diorítico potássico a leste do Batólito de Itaporanga. Fatores de normalização de Evensen et al. (1978)

mixed with the Itaporanga must had a common source. Another evidence of diffusionally controlled equilibrium is the growth of microcline megacrysts in mafic dikes, with the same composition as the microcline in the host rock. This mafic dikes intruded when the host rock still had some liquid.

The field evidence for magma mixing is reinforced by the chemistry of the rocks. Major elements oxides plotted against $\mathrm{SiO}_{2}$ show near linear trend, with the hybrid samples placed at intermediate position between felsic and mafic ones (Fig. 6). Trace elements plotted against $\mathrm{SiO}_{2}$ show a strong scatter (Fig. 10), suggesting different mixing proportions, variable mobility during diffusion, crystal fractionation during and before the mixing event, and problems of collecting representative samples.

Figures 11 and 12 represent further evidence of mixing where trace element ratio-ratio fit a hyperbolic distribution and the plot of one of the original ratios against the denominators ratio gives a straight line (Vogel et al. 1987). The degree of scatter may be explained by the processes mentioned above.

The homogeneity of the oxygen isotope data (Mariano et $a l$. in press), the igneous nature of the mafic enclaves, and the intermediate initial ${ }^{87} \mathrm{Sr} /{ }^{86} \mathrm{Sr}(0.7058$, Sial et al. 1989) suggest that assimilation of crustal material had little influence on the lithologic variation observed in the pluton. The Itaporanga batholith is suggested to have its origin at lower crustal levels from an igneous source, previously enriched in $\mathrm{K}$ and LREE, which underwent some degree of crystal fractionation and mixed at a magma chamber level with a potassium diorite magma. The mixing event was enhanced by shear along a deep crustal shear zone (Boqueirão dos Cochos Fault, see geologic map Fig. 2), which promoted crustal extension favoring the ascent and final diapiric emplacement of the composite pluton.

The field evidence for magma mixing are the most cogent evidence to suggest that this process was responsible for the lithologies observed in the pluton. Testimonies of incomplete mixing are commonly observed throughout the Itaporanga 
batholith as mafic enclaves with cuspate contacts, pillow-like structures, and migmatite-like features.

Major and trace elements chemistry of the mafic enclaves, together with microprobe data suggest a common source for the enclaves and the potassium diorite stock eastern of the Itaporanga pluton.

Acknowledgments We are grateful to FINEP/PADCT for financial suport. Thanks also go to CNPq and CAPES which provided one of us (G.M.) with scholarship for graduate studies at the University of Georgia, U. S. A. This work is portion of a Ph. D. dissertation of one of us (G. M.) presented at the University of Georgia, under the direction of Dr. Norman Herz, to whom G.M. would like to express his gratitude. During the several phases of this work the facilities of the University of Georgia and the Center for Granite Studies (NEG) in the Universidade Federal de Pernambuco, Brazil, were used.

\section{REFERENCES}

ALMEIDA, F. F. M. de; LEONARDOS JÚNIOR, O.H.; VALENÇA J. 1967. Granitic rocks of Northeastern South America. Recife, IUGS/UNESCO.41p.

BARBOSA, O. 1970. Geologia econômica da parte da região do médio São Francisco, Nordeste do Brasil. Petrópolis, PROSPEC S.A., SUDENE, Div. Geol., 68p. In: Almeida, F. F. M. de \& Hasui, Y., eds. O Pré-Cambriano do Brasil. Edgard Blucher Ltda. 379p.

BATCHELOR, R. A. \& BOWDEN, P. 1985. Petrogenetic interpretation of granitoid rock series using multicationic parameters. Chem. Geol., 48:43-65.

BRITO NEVES, B. B. de 1975. Regionalização geotectônica do Pré-Cambriano nordestino. São Paulo. 198 p. (Ph.D. thesis IG Universidade de São Paulo)

BROOKS, C. K. 1977. Example of magma mixing from the Kialineq district of East Greenland. Geol. Soc. Denmark Bull., 26:77-83

BROWN, G. C.; THORPE, R. S.; WEEB, P. C. 1984. The geochemical characteristics of granitoids in contrasting arcs and comments on magma sources. J. Geol. Soc. London, 141:413-426,

BROWN, P. E. \& BECKER, S. My 1986. Fractionation hybridization and magma mixing in the Kialineq Centre east Greenland. Contrib. Mineral. Petrol., 92:57-70.

COOK, N. D. T. 1988. Diorites and associated rocks in the Auglen complex at the Neck, Northwestern Stewart Island New Zealand: an example of magma mixing. Lithos, 21:247-267.

COX, K. G., BELL, J. D.; PANKHUST, R. J. 1979. The interpretation of igneous rocks. London, George Allen \& Unwin Ltd. 450 p.

DORAIS, M. J. 1987. The mafic enclaves of the Dinkey Creek granodiorite and the Carpenter Ridge tuff. A nuneralogical, textural and geochemical study of their origins with implications for the generation of silicic bathoKths. Athens. 185p. (Ph.D. thesis, University of Georgia).

DUTRA, C. V. 1984. Método para determinação de traços e sub-traços de terras raras em rochas por espectrometria de plasma (TCP) Aplicação em petrogênese. In: CONGR. BRÁS. GEOL., 33, Rio de Janeiro, 1984. Anais... Rio de Janeiro, SBG. v. 10, p. $4792-4805$

EVENSEN, N. M. HAMILTON, P. J. O'NIONS, R. K. 1978. Rare earth element abundances in chondrite meteorites. Geoch. Cosmoch. Acta., 42:1199-1212.

FERRARA, G.; PREITE-MARTINEZ, M.; TAYLOR JÚNIOR, H. P.; TONARINI, S.; TURI, B. 1986. Evidence of crustal assimilation, mixing of magmas and a Sr-rich (87) upper mantle. Contrib. Mineral. Petrol., 92(3):269-280. (Mineral. Abst., December, 1986).

GROMET, L. P. \& SILVER, L. T. 1983. Rare earth element distribution among minerals in granodiorites and their petrogenetic implications. Geochem. Cosmochem. Acta., 47:925-939.

HUPPERT, H.E.; SPARKS, R. S. J. ; TURNER, J. S. 1983. Laboratory investigations of viscous effects in replenished magma chambers. Earth Planetary Science Letters, 65:377-381.

IRVINE, T. N. \& BARAGAR, W. R. A. 1971. A guide do chemical classification of the common volcanic rocks. Canadian J. Earth Science., 8:523-548.

KOUCHI, A. \& SUNAGAWA, I. 1983. Mixing basaltic and dacitic magmas by forced convection. Nature, 304:527-528.

LEAKE, B. E. 1978. Nomenclature of tanptaboles. Canadian Mineral., 16:501-520.

MARIANO, G. 1989. Magma mixing origin of a potassic calc-alkaBne pluton: the Itaporanga batholith, state of Paraiba, Northestern Brazil. Athens. 180p. (Ph.D. thesis, University of Georgia).

MARIANO, G.; SIAL, A. N.; HERZ, N. 1990. Oxygen isotope geochemistry of a potassic porphyritic calc-alkalic composite pluton: the Itaporanga batholith state of Paraíba, Northeastern Brazil. Rev. Bras. Geoc., 20(1/4):

MEHNERT, K.R. 1968. Migmatites and the origin of granitic rocks. New York, Elsevier. 393 p

REID Jr., J. B. \& HAMILTON, M. A. 1987. Origin of Sierra Nevadan granite: evidence for small scale composite dikes. Contrib. Mineral. Petrol., 96:441-454.

SANTOS, E. J.; COUTINHO, M.E.; COSTA, M. P.; RAMALHO, R. 1984. A região de dobramentos Nordeste e a Bacia do Parnaíba, incluindo o Cráton de São Luis e as bacias marginais. In:
SCHOBBENHAUS, C. et al. coord. Geologia do Brasil, Brasília, p. 131-189. DNPM

SIAL, A. N. 1984a. Padrão regional de isòtopos de oxigênio em granitóides do espaço Cachoeirinha, Nordeste, Brasil. In: CONGR. BRÁS. GEOL., 33, Rio de Janeiro, 1984. Anais... Rio.de Janeiro, SBG. v. 8, p.2710-2722.

SIAL, A. N. 1984b. Litogeoquímica de elementos terras raras na caracterização de granitóides do espaço Cachoeirinha, Nordeste Brasil. In: CONGR. BRÁS. GEOL., 33, Rio de Janeiro, 1984. Anais... Rio de Janeiro, SBG. v. 8, p.2697-2709.

SIAL, A. N. 1986. Granite types in Northeastern Brazil. Current knowledge. Rev. Bras. Geoc., 16(1)54-72.

SIAL, A. N. 1987. Granitoid rock of Northeastern Brazil. In: INTERN. SYMP. ON GRANITES AND ASSOC. MINERAL. (ISGAM), Salvador, Brasil, p.61-69.

SIAL, A. N. \& FERREIRA, V. P. 1988. Brasiliano age peralkaline plutonic rocks of the central structural domain, Northeastern Brazil. Rendiconti delia Societá ItaKana di Mineralogia e Petrologia, 43(2):307-342.

SIAL, A. N.; FERREIRA, V. P.; MARIANO, G. 1987. Proterozoic granitoids western Pernambuco and Paraíba states, Northeast Brazil. In: INTERN. SYMP. ON GRANITES AND ASSOC. MINERAL. (ISGAM), Salvador, Brazil. Field Trip Guide... Salvador, p. 9-29.

SIAL, A. N.; LIMA, E. S.; PESSOA, D. A.; CASTRO, C.; VILLAROEL, H. S.; BORBA, G. S.; RODRIGUES DA SILVA, M. R. 1981a. Petrologia e geoqufmica do Batólito de Bodocò e stocks de Serrita, Pernambuco. In: SIMPÓSIO DE GEOLOGIA DO NORDESTE, 10, Recife, 1981. Atas... Recife, SBG. p.338-401.

SIAL, A. N; LIMA E. S. PESSOA D A · CASTRO C · VILLAROEL, H. S. RODRIGUES DA SILVA, M.R.; BORBA, G.S.; LIMA, G.R. 1981b. Geoquímica de dois stocks granodioríticos de Serrita (PE): elementos maiores. Estudos e Pesquisas, 4:27-52.

SIAL, A. N.; MARIANO, G.; FERREIRA, V.P. 1989. Isotope geochemistry of Brasiliano age, coarsely porphyritic, $\mathrm{K}$-calc-alkaline granitoide and associated K-diorites, Northeast Brazil. In: CONGR. BRAS. GEOQ., 2, Rio de Janeiro, 1989. Anais... Rio de Janeiro, p.229-240.

SILVA FILHO, M. A. 1985. Projeto Cachoeirinha. Recife, DNPM/CPRM. v. 1,128p.

STRECKEISEN, A. L. \& LEMAITRE, R. W. 1979. A chemical approximation to the modal QAPF classification of the igneous rocks. Newes Jahrbuch fur Mineralogie Abhandlugen, 136:169-206.

THOMPSON, R. N.; MORRISON, M. A.; DICKIN, A. P.; HENDRY, G. L. 1983. Continental flood basalts... arachnids rule ok? In: HAWKESWORTH, C. J. \& NORRY, M. J. eds. Continental basalts and mande xenoUths. Cambridge, Shiva Geoloy Series. p.158-185.

VOGEL, T.A.; YOUNKER, L. W.; WILBAND, J. T.; KAMPMUELLER, E. 1984. Magma mixing: the Manco suite, Isle of Skye, Scotland. Contrib. Mineral. Petrol., 87:231-241.

VOGEL, T. A.; YOUKER, L. W.; SCHURAYTZ, B. C. 1987. Constraints on magma ascent, emplacement, and eruption: geochemical and mineralogical data from drill-core samples at Obsidian dome, Inyo Chain, California. Geology, 15:405-408.

WHALEN, J. B. \& CURRIE, K. L. 1984. The Topsails igneous terrane, Western Newfoundland: evidence for magma mixing. Contrib. Mineral. Petrol., 87:319-327.

WOOD, D. A. 1979. A variable veined sub-oceanic upper mantle-genetic significance for mid-ocean ridge basalts from geochemical evidence. Geology, 7:499-503.

WIEBE, R. A. \& WILD, T. 1983. Fractional crystallization and magma mixing in the Tigalak layered intrusion, the Nain anorthosite complex, Labrador. Contrib. Mineral. Petrol., 84:327-344

MANUSCRITO A645

Recebido em 23 de marco de 1990 Revisão do autor em 17 de abril de 1990 Revisão aceita em 19 de abril de 1990 